\title{
Manajemen Sekolah Adiwiyata (Studi Multisitus di SDN Kauman 1 Malang dan SD Plus Al-Kautsar Malang)
}

\author{
Rizal Ar Rasyid*, Mustiningsih, Imron Arifin \\ Universitas Negeri Malang, Jl. Semarang No. 5 Malang, Jawa Timur, Indonesia \\ *Penulis korespondensi, Surel: rizalarrasyid31@gmail.com
}

Paper received: 28-9-2021; revised: 12-10-2021; accepted: 19-10-2021

\begin{abstract}
The purpose of this study was to describe adiwiyata school planning, organizing adiwiyata schools, implementing adiwiyata schools, and supervising adiwiyata schools. This study used a qualitative approach with a type of multisite case study. This is because researchers describe, analyze, and juxtapose the management of adiwiyata schools. The technique used by researchers is observation, interviews, and documentation. Research results: (1) school planning adiwiyata; (2) organizing adiwiyata schools; (3) implementation of adiwiyata schools; and (4) supervision of adiwiyata schools.
\end{abstract}

Keywords: management; school management; adiwiyata school

\begin{abstract}
Abstrak
Tujuan penelitian ini adalah untuk mendeskripsikan perencanaan sekolah adiwiyata, pengorganisasian sekolah adiwiyata, pelaksanaan sekolah adiwiyata, dan pengawasan sekolah adiwiyata. Penelitian ini menggunakan pendekatan kualitatif dengan jenis penelitian studi kasus multi situs. Hal ini karena peneliti mendeskripsikan, menganalisis, dan menyandingkan tentang manajemen sekolah adiwiyata. Teknik yang digunakan peneliti adalah observasi, wawancara, dan dokumentasi. Hasil penelitian: (1) perencanaan sekolah adiwiyata; (2) pengorganisasian sekolah adiwiyata; (3) pelaksanaan sekolah adiwiyata; dan (4) pengawasan sekolah adiwiyata.
\end{abstract}

Kata kunci: manajemen; manajemen sekolah; sekolah adiwiyata

\section{Pendahuluan}

Adiwiyata merupakan salah satu program yang diselenggarakan oleh Kementerian Lingkungan Hidup. Adiwiyata merupakan tempat yang dianggap layak untuk memperoleh ilmu pengetahuan, norma, serta etika yang ada dalam lingkungan. "Program adiwiyata bertujuan untuk mewujudkan warga sekolah yang bertanggung jawab dalam upaya perlindungan dan pengelolaan lingkungan hidup melalui tata kelola sekolah yang baik untuk mendukung pembangunan berkelanjutan" (Kementerian Lingkungan Hidup Republik Indonesia, 2011). "Demi meraih tujuan program adiwiyata, maka ditetapkan 4 komponen program yang menjadi kesatuan utuh dalam mencapai sekolah adiwiyata. Keempat komponen tersebut, yaitu: kebijakan berwawasan lingkungan, pelaksanaan kurikulum berbasis lingkungan, kegiatan lingkungan berbasis partisipatif, serta pengelolaan sarana pendukung ramah lingkungan" (Kementerian Lingkungan Hidup Republik Indonesia, 2011).

Manusia merupakan bagian yang tidak terpisahkan dari lingkungan hidupnya, serta lingkungan juga dapat mempengaruhi manusia tersebut. Seiring dengan pertumbuhan penduduk yang semakin pesat, pemenuhan terhadap kebutuhan manusia meningkat, serta berkembangnya ilmu pengetahuan dan teknologi telah mempercepat kerusakan lingkungan hidup seperti pencemaran atau polusi. Oleh sebab itu, perlu dilakukan suatu upaya yang dapat 
menjaga kelestarian lingkungan hidup khususnya dalam lembaga pendidikan, seperti program adiwiyata.

Sekolah adiwiyata dituntut untuk memiliki sekolah imbas yang nantinya dibina. Pembinaan terhadap sekolah imbas tersebut dilaksanakan selama kurang lebih 1 tahun dan harus menyesuaikan dengan kemampuan yang dimiliki oleh sekolah binaan tersebut.

Dampak lain dilaksanakannya program adiwiyata oleh sekolah adalah pembelajaran yang berlangsung di sekolah mengalami peningkatan karena dengan adanya lingkungan yang bersih, sehat, dan hijau membuat peserta didiknya merasa nyaman dalam belajar. Selain itu, guru juga mendapat manfaat yang cukup besar dengan adanya program adiwiyata, yaitu guru dengan mudah menemukan media yang diajarkan kepada peserta didiknya. Tidak cukup hanya itu, adanya program adiwiyata membuat para peserta didik yang berada di sekolah menjadi lebih peduli terhadap lingkungannya, baik di dalam sekolah maupun di luar sekolah. Adanya program adiwiyata juga membuat para peserta didik belajar secara nyata karena langsung mempraktekkan kegiatan yang berhubungan dengan lingkungan di sekolahnya.

Sekolah merupakan suatu organisasi di bidang pendidikan yang harus dikelola dengan baik. Sekolah dinilai oleh masyarakat tentang kualitas dalam mendidik peserta didik dan dilihat dari bagaimana cara sekolah tersebut dikelola dengan baik oleh kepala sekolah. Proses pendidikan di sekolah tidak terlepas dari pengaruh lingkungan. Oleh sebab itu, lingkungan harus diperhatikan agar proses pembelajaran mencapai tujuan pendidikan. Institusi pendidikan mulai dari sekolah dasar hingga tingkat perguruan tinggi diharapkan turut serta dalam memberikan sumbangsih dan peranannya masing-masing untuk mewujudkan tujuan dari perlindungan pengelolaan lingkungan hidup.

Dikatakan sekolah adiwiyata bukan hanya tampilan fisik yang hijau dan rindang, namun merupakan wujud sekolah yang memiliki program dan aktivitas pendidikan yang mengarah pada kearifan terhadap lingkungan. Untuk mencapai tujuan sekolah adiwiyata terdapat beberapa komponen yang harus diperhatikan, di antaranya adalah: kebijakan berwawasan lingkungan, pelaksanaan kurikulum berbasis lingkungan, kegiatan lingkungan berbasis partisipatif, dan pengelolaan sarana dan prasarana pendukung ramah lingkungan.

Sekolah adiwiyata dalam melaksanakan segala kegiatannya selaras dengan program adiwiyata. Sekolah adiwiyata merupakan salah satu sekolah yang peduli terhadap lingkungan sekolahnya. Oleh karena itu, lingkungan yang mampu meningkatkan kualitas pembelajaran harus dikelola dengan sebaik mungkin. Pengelolaan ini bisa menggunakan proses-proses yang ada dalam manajemen yang meliputi kegiatan perencanaan, pengorganisasian, penggerakan, dan pengendalian, jika diperlukan tindak lanjut terhadap pengelolaan tersebut bisa dilakukan dengan pengawasan terhadap segala kegiatan yang telah dilaksanakan.

SDN Kauman 1 Malang merupakan sekolah rujukan yang kini telah menjadi sekolah adiwiyata. Sekolah ini memiliki program adiwiyata yang patut untuk ditiru, seperti halnya dengan turut meramaikan peringatan-peringatan hari lingkungan hidup. Selain itu, sekolah juga berupaya untuk tidak membuang sampah sekolah ke luar dari lingkungan. Sampah tersebut dijadikan sekolah sebagai daur ulang yang memiliki manfaat.

SD Plus Al-Kautsar Malang merupakan salah satu sekolah swasta yang telah memiliki gelar sekolah adiwiyata di Malang. Sekolah ini sangatlah memiliki komitmen yang tinggi ketika 
melaksanakan program adiwiyata. Hal ini terbukti dari awal bahwa sekolah ini mampu melaksanakan program adiwiyata tanpa bimbingan dari sekolah lain. Dari komitmen tersebut akhirnya sekolah mampu mencapai penghargaan sekolah adiwiyata.

Alasan peneliti ingin melakukan penelitian di SDN Kauman 1 Malang adalah karena ingin mengetahui lebih lanjut bagaimana proses manajemen yang dilakukan. Selain itu, SDN Kauman 1 Malang merupakan satu-satunya sekolah dasar rujukan di Kota Malang dan telah mampu meraih juara 1 tentang Sekolah Adiwiyata. Alasan peneliti ingin melakukan di SD Plus AlKautsar Malang adalah karena sekolah tersebut merupakan sekolah swasta yang mampu mencapai adiwiyata.

\section{Metode}

Penelitian ini menggunakan pendekatan kualitatif dengan jenis penelitian studi kasus multi situs. Hal ini karena peneliti mendeskripsikan, menganalisis, dan menyandingkan tentang manajemen sekolah yang ada di SDN Kauman 1 Malang dan SD Plus Al-Kautsar Malang. Teknik yang digunakan peneliti adalah observasi, wawancara, dan dokumentasi. Data diproses dengan analisis data kasus tunggal dan data lintas kasus. Peneliti juga menguji dengan menggunakan triangulasi, pengecekan anggota, meningkatkan ketekunan, dan kecukupan bahan referensi.

\section{Hasil dan Pembahasan}

\subsection{Hasil}

Hasil yang diperoleh dari penelitian pada SDN Kauman 1 Malang dan SD Plus Al-Kautsar Malang sebagai berikut. Perencanaan meliputi (1) Sosialisasi dari Dinas Lingkungan Hidup dan Dinas Pendidikan; (2)Visi misi sekolah bermuatan peduli lingkungan; (3) Memperhatikan empat komponen penting adiwiyata (kebijakan, kurikulum, sarana dan prasarana, dan partisipatif); (4) Sosialisasi dari tim adiwiyata kepada warga sekolah mengenai program adiwiyata; (5) Minimal anggaran dana sebesar dua puluh persen. Pengorganisasian meliputi (1) Penetapan tim Adiwiyata yang ditunjuk kepala sekolah disertai dengan adanya SK; (2) Pembentukan pokja-pokja yang sesuai dengan tugas, pokok, dan fungsi; (3) Penetapan anggota pokja dipilih bagi peserta didik yang kompeten. Pelaksanaan meliputi (1) Integrasi program adiwiyata ke dalam pembelajaran; (2) Kegiatan membersihkan lingkungan yang rutin dilaksanakan pagi hari sebelum masuk kelas; (3) Jumat bersih yang diikuti semua warga sekolah; (4) Peringatan hari lingkungan hidup; (5) Kegiatan masing-masing pokja sesuai jadwal yang ada; (6) Membina sekolah imbas setidaknya sepuluh sekolah. Pengawasan meliputi (1) Pelaporan dari anggota pokja ke penanggung jawab pokja; (2) Penggunaan group WhatsApp untuk memudahkan proses pengawasan berlangsung; (3) Pengecekan RPP oleh kepala sekolah; (4) Pemantauan kegiatan pokja oleh penanggung jawab pokja.

\subsection{Pembahasan}

\subsubsection{Perencanaan Sekolah Adiwiyata}

Program adiwiyata yang dilakukan secara berkelanjutan agar rasa tanggung jawab dan kepedulian siswa-siswinya terhadap lingkungan sekitarnya dapat tumbuh. Perencanaan sekolah adiwiyata dilaksanakan untuk menciptakan siswa-siswi yang peduli terhadap lingkungan di sekitarnya. Selain itu juga untuk menciptakan suasana belajar yang nyaman, 
indah, bersih, asri, dan sejuk sehingga proses belajar mengajar akan berlangsung dengan kondusif. Seperti pendapat dari Mulyono (2010), perencanaan merupakan proses yang sistematik untuk menetapkan setiap keputusan, kegiatan, hingga langkah-langkah yang harus ditempuh agar bisa mencapai tujuan secara efektif dan efisien.

Perencanaan program adiwiyata awal mula adalah dengan adanya sosialisasi dari pihak Dinas Pendidikan dan Dinas Lingkungan Hidup terkait pelaksanaan program adiwiyata. Visi misi yang dimiliki oleh sekolah juga bermuatan tentang peduli terhadap lingkungan. Terdapat empat komponen penting adiwiyata yang harus diperhatikan oleh sekolah (kebijakan, kurikulum, sarana dan prasarana, dan partisipatif). Sekolah juga melakukan kegiatan sosialisasi terhadap program adiwiyata tersebut, hal ini dilakukan dengan maksud agar semua warga sekolah bisa mengetahui dan mampu memberikan saran dan masukan terhadap program tersebut. Sekolah adiwiyata telah menetapkan anggaran dananya minimal sebesar dua puluh persen. Anggaran dana tersebut diperoleh sekolah dari pemerintah.

Penting bagi sekolah untuk bisa menetapkan proses perencanaan yang matang agar nantinya mampu melaksanakan program adiwiyata dengan lancar tanpa kendala serta mampu mencapai tujuan dengan efektif dan efisien.

\subsubsection{Pengorganisasian Sekolah Adiwiyata}

Agar dapat berjalan dengan lancar, kepala sekolah haruslah mampu untuk membagi tugas dan fungsi pada tim adiwiyata tersebut. Peneliti menemui proses pengorganisasian tertuang dalam struktur tim adiwiyata yang telah dibuat berdasarkan keputusan bersama tim adiwiyata dan kepala sekolah. Prakteknya hampir semua warga di sekolah memiliki peranannya sendiri, setiap pokja juga memiliki penanggung jawabnya yang berasal dari guru. Seperti yang dikatakan oleh Sagala (2006), pengorganisasian merupakan salah satu bentuk niat antara guru dan siswa untuk mencapai tujuan proses pembelajaran.

Sependapat dengan pernyataan Fattah (2013), pengorganisasian merupakan proses pembagian tugas ke dalam kelompok yang kecil, pemberian wewenang kepada pihak yang pantas, pengalokasian sumber daya yang ada hingga mengkoordinasikan setiap kegiatan agar mampu mencapai tujuan dari organisasi.

Sedangkan pendapat dari Barnawi dan Arifin (2012), pengorganisasian merupakan kegiatan menyusun struktur organisasi suatu instansi yang harus disesuaikan dengan tujuan organisasi, sumber daya, dan lingkungan dari organisasi itu sendiri. Pengorganisasian pada dua sekolah tersebut dilakukan dengan membagikan tugas dan fungsi dari masing-masing anggota. Hal tersebut dapat dibuktikan dengan adanya pokja-pokja serta mengintegrasikan program adiwiyata ke dalam pembelajaran. Setiap anggota adiwiyata tersebut berkesempatan untuk mengikut kegiatan pelatihan, workshop, serta sosialisasi.

Kegiatan pengorganisasian dalam suatu organisasi sangatlah penting untuk dijalankan karena dengan pengorganisasian yang tepat maka setiap kegiatan atau program yang direncanakan dapat berjalan dengan baik serta mampu mencapai tujuan secara efektif dan efisien. 


\subsubsection{Pelaksanaan Sekolah Adiwiyata}

Pelaksanaan program adiwiyata yang paling penting adalah dengan mengintegrasikan program adiwiyata ke dalam pembelajaran. Harapan dimasukkannya program adiwiyata ke dalam pembelajaran adalah dapat dilaksanakannya program secara menyeluruh. Kegiatan tersebut meliputi kegiatan seperti pemberian materi dan tugas selama proses pembelajaran dilakukan. Sementara itu ada juga kegiatan lain di luar pembelajaran yang meliputi kegiatan yang berkaitan dengan lingkungan hidup seperti kegiatan pokja dan peringatan hari besar lingkungan.

Seperti yang dipaparkan oleh Lusty dan Maisyaroh (2012), pendidikan lingkungan hidup dapat diintegrasikan ke dalam materi-materi yang diajarkan di sekolah, pelaksanaan bisa dilakukan tanpa proses pemberian ceramah tapi langsung dengan praktek lapangan.

Pelaksanaan program adiwiyata diharapkan mampu untuk meningkatkan kesadaran peduli lingkungan dari semua warga yang ada di sekolah. Selain itu dengan adanya program adiwiyata tersebut mampu menciptakan suasana yang bersih, asri, nyaman dan diharapkan pelaksanaan proses belajar mengajar dapat berlangsung dengan kondusif.

Kebijakan dari program adiwiyata adalah harus adanya tim adiwiyata. Adapun koordinator dalam tim adiwiyata sangat penting yang ditunjuk langsung oleh kepala sekolah masing-masing. Ketua tersebut memiliki tugas dalam mengawasi jalannya program adiwiyata yang berkaitan dengan lingkungan hidup seperti pokja, dan pemeliharaan dan perawatan lingkungan. Agar program adiwiyata dapat berlangsung secara optimal, kedua sekolah mengajak partisipasi warga sekolah dan warga sekitar. Selain itu partisipasi warga tersebut merupakan salah satu peran yang penting dalam dokumen adiwiyata. Peran stakeholders juga tak kalah penting, mereka juga memiliki peran dalam mencarikan bantuan kepada pihak luar dan mencarikan bantuan dana secara berkelanjutan.

Seperti pendapat yang diutarakan oleh Fattah (2013), penggerakan merupakan suatu proses yang dilakukan manajer untuk mengarahkan dan mempengaruhi para bawahannya untuk mengerjakan tugas atau pekerjaan tertentu agar bisa bekerja sama dengan menyenangkan. Pendapat tersebut juga diperkuat dengan pendapat Kurniadi dan Machali (2012), penggerakan merupakan upaya menggerakkan tenaga atau sumber daya manusia dan mendayagunakan setiap fasilitas yang ada secara maksimal untuk pekerjaan bersama.

Selama pelaksanaan program adiwiyata, sekolah dibantu oleh pihak luar dan dalam yang berperan untuk mendukung pelaksanaan program adiwiyata. Program adiwiyata di kedua sekolah dilakukan secara berkesinambungan dan partisipatif. Adanya fasilitas atau sarana prasarana sekolah yang memadai dapat membantu lancarnya pelaksanaan program adiwiyata.

\subsubsection{Pengawasan Sekolah Adiwiyata}

Pengawasan program adiwiyata dilakukan dengan maksud untuk mengetahui ketercapaian dari program tersebut dan apa saja hambatan serta bagaimana solusi yang akan diambil. Hasil dari pengawasan tersebut nantinya digunakan sebagai tolak ukur bagi kepala sekolah, tim adiwiyata, hingga warga sekolah ketika akan melaksanakan program yang baru. 
Peneliti menemukan bahwa pengawasan yang dilakukan oleh kedua sekolah dilakukan selama pelaksanaan program. Adapun kegiatan tersebut seperti mengawasi kegiatan yang dilakukan di pokja dan pada peringatan hari besar lingkungan. Selain itu, sekolah juga menggunakan alat media berupa aplikasi WhatsApp untuk melaporkan setiap kegiatan yang dilakukan di masing-masing pokja yang ada. Pengawasan dilakukan oleh penanggung jawab pada masing-masing pokja yang nantinya dilanjutkan kepada ketua adiwiyata.

Hal ini sependapat dengan pernyataan dari Siagian (2003), pengawasan merupakan proses mengawasi seluruh kegiatan yang dilakukan pada suatu organisasi dengan maksud agar kegiatan tersebut berjalan sesuai dengan rencana yang sudah ditetapkan sebelumnya. Selain itu, pendapat lain yang juga sependapat adalah dari Kurniadi dan Machali (2012), pengawasan merupakan proses pengamatan, pengukuran terhadap suatu kegiatan dan hasil yang diperoleh untuk dibandingkan dengan standar yang sudah ditetapkan sebelumnya.

Kegiatan pengawasan dalam program adiwiyata pada kedua sekolah sangatlah penting untuk dilaksanakan karena dengan dilaksanakan pengawasan dapat diketahui bagaimana ketercapaian program yang sudah ditetapkan. Kegiatan evaluasi dapat dilakukan dengan cara memantau setiap kegiatan yang dilaksanakan serta bisa melihat dari dokumen atau laporan dari perkembangan program adiwiyata. Evaluasi tersebut nantinya bisa digunakan sebagai pedoman atau tolak ukur bagi kepala sekolah dan tim adiwiyata untuk meningkatkan keberhasilan program adiwiyata selanjutnya.

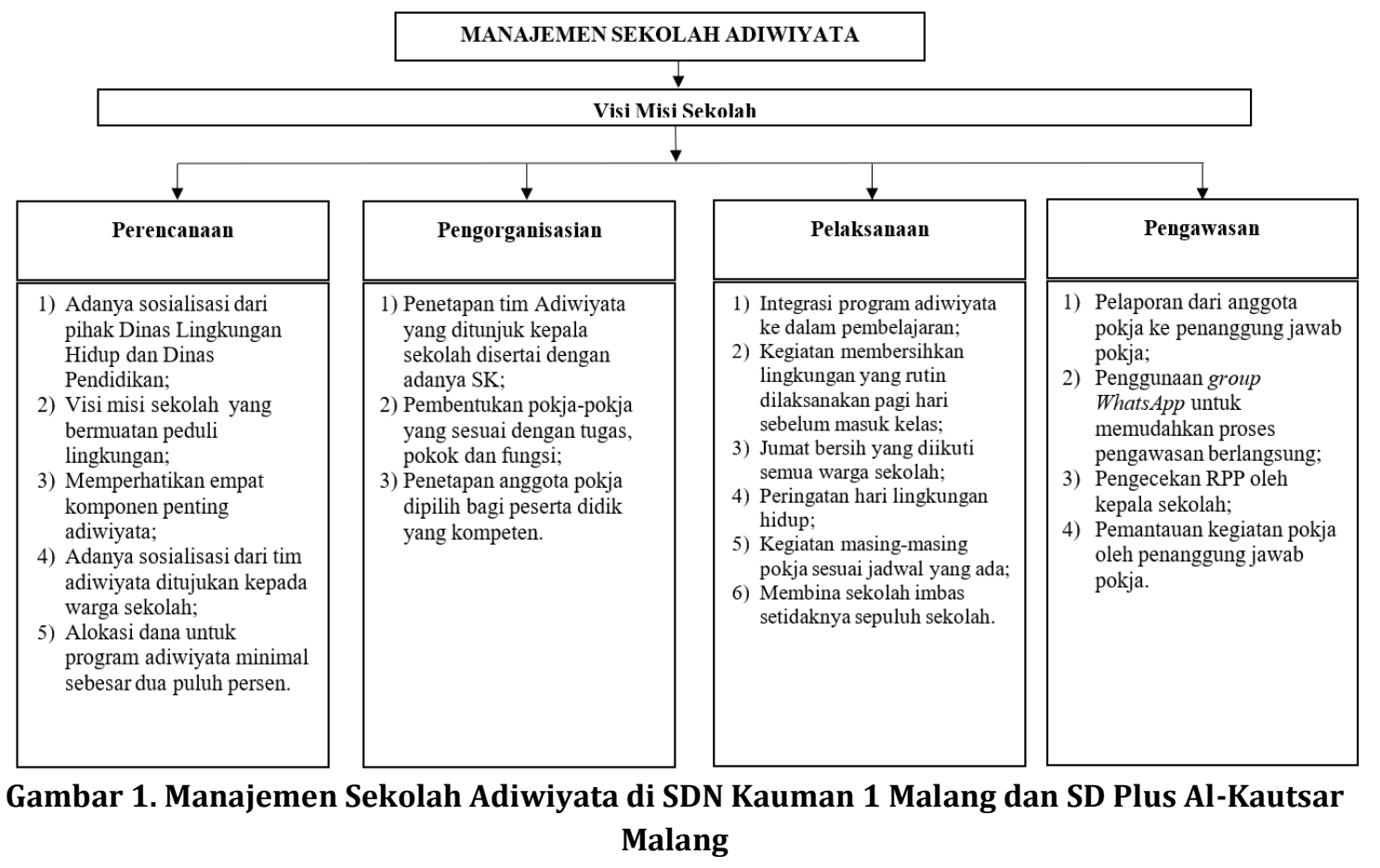

\section{Simpulan}

Perencanaan yang dilakukan terkait program adiwiyata yaitu dimulai dengan adanya sosialisasi dari pihak Dinas Pendidikan dan Dinas Lingkungan Hidup terkait program adiwiyata. Visi misi dari sekolah bermuatan peduli terhadap lingkungan. Sekolah adiwiyata juga memiliki empat komponen penting yang diperhatikan (kebijakan, kurikulum, sarana dan 
prasarana, dan partisipatif). Kemudian pihak sekolah khususnya tim adiwiyata sosialisasi terhadap program adiwiyata kepada warga sekolah. Adanya alokasi anggaran dana untuk program adiwiyata minimal sebesar dua puluh persen dari anggaran sekolah.

Kepala sekolah membentuk tim adiwiyata yang telah dilampiri SK. Setelah tim adiwiyata terbentuk maka program adiwiyata ditentukan diiringi dengan pembentukan pokja-pokja. Masing-masing pokja terdiri dari siswa-siswi dan penanggung jawab, yaitu guru. Perekrutan anggota pokja dengan langsung memilih siswa-siswi yang kompeten di dalam kelas dan bisa dilaksanakan dengan memilih siswa-siswi yang sudah terjaring selama proses yang panjang, yaitu dimulai dari kader tiwisada, dokter kecil, kader lingkungan, kemudian baru bisa menjadi anggota pokja.

Pelaksanaan diintegrasikan ke dalam pembelajaran, sehingga setiap hari siswa-siswi mendapatkan pengetahuan tentang peduli lingkungan. Guru memberikan materi peduli lingkungan selama di kelas melalui proses pembelajaran. Selain itu sekolah juga melaksanakan kegiatan di luar pembelajaran. Kedua sekolah menerapkan kegiatan memungut sampah sebelum masuk sekolah hanya saja penamaan kegiatan tersebut berbeda, semut samper (sejenak memungut sampah berserakan) dan kegiatan operasi semut. Adanya pelaksanaan Jumat bersih yang rutin dilaksanakan oleh semua warga sekolah. Peringatan hari lingkungan hidup juga tidak lupa dilaksanakan oleh kedua sekolah yang merupakan cerminan dari sekolah adiwiyata. Selain itu, pokja-pokja juga melaksanakan tugasnya masing-masing setiap hari secara rutin oleh anggota pokja. Kedua sekolah tersebut juga memiliki sekolah imbas yang dibina secara terus menerus agar bisa menjadi sekolah adiwiyata juga.

Penanggung jawab pokja (guru) mengevaluasi pekerjaan yang sudah dilaporkan anggota pokja (siswa-siswi) pada buku pokja. Laporan tersebut diberikan kepada tim adiwiyata untuk ditindaklanjuti. Pengawasan dilaksanakan dengan cara mendatangi masingmasing pokja yang bekerja. Sekolah juga menggunakan media sosial WhatsApp untuk melaksanakan pengawasan. Kepala sekolah juga mengawasi sistem pembelajaran dengan cara melihat RPP guru apakah sudah sesuai dengan standar program adiwiyata atau belum. Pengawasan dilaksanakan dengan cara memantau langsung kegiatan yang dilaksanakan oleh para warga sekolah, terlebih lagi pada pokja-pokja adiwiyata.

\section{Daftar Rujukan}

Barnawi \& Arifin, M. (2012). Manejemen Sarana dan Prasarana. Yogyakarta: Ar-Ruzz Media.

Fattah, N. (2013). Landasan Manajemen Pendidikan. Bandung: Remaja Rosdakarya.

Gunawan, I. \& Benty, D. D. N. (2017). Manajemen Pendidikan: Suatu Pengantar Praktik. Bandung: Alfabeta. CV. Imron, A. (2003). Manajemen Pendidikan: Substansi Inti dan Ekstensi. Malang: Universitas Negeri Malang.

Informasi Mengenai Adiwiyata. Kementerian Lingkungan Hidup Republik Indonesia. (Online), (http://www.menlh.go.id/informasi-mengenai-adiwiyata/), diakses 4 Desember 2018.

Kamus Bahasa Indonesia. (2008). Jakarta: Pusat Bahasa Departemen Pendidikan Nasional.

Kementerian Lingkungan Hidup Republik Indonesia. (2011). Sekolah Peduli dan Berbudaya Lingkungan. Jakarta: Deputi Bidang Komunikasi.

Kementerian Negara Lingkungan Hidup. (2012). Panduan Adiwiyata. Jakarta: Deputi Bidang Komunikasi Lingkungan dan Pemberdayaan Masyarakat.

Kurniadin, D. \& Machali, I. (2012). Manajemen Pendidikan (Konsep dan Prinsip Pengelolaaan Pendidikan). Jogjakarta: Ar-Ruzz Media. 
Jurnal Pembelajaran, Bimbingan, dan Pengelolaan Pendidikan, 1(10), 2021, 807-814

Lusty \& Maisyaroh. (2015). Peran Warga Sekolah Dalam Penerapan Pendidikan Lingkungan Hidup. Jurnal Ilmu Pendidikan. 23(5), 63-68

Miles, Huberman \& Saldana, J. (2014). Qualitative Data Analysis: A Methods Sourcebook. United States of America: SAGE Publications, Inc.

Moleong, L. J. (2012). Metodologi Penelitian Kualitatif. Bandung: PT. Remaja Rosdakarya.

Mulyono. (2010). Manejemen Adiministrasi dan Organisasi Pendidikan. Jogjakarta: Ar-Ruzz Media.

Peraturan Menteri Lingkungan Hidup Republik Indonesia Nomor 05 Tahun 2013. Pedoman Pelaksanaan Program Adiwiyata. (Online), (http://jdih.menlh.go.id), diakses 01 Maret 2017.

Puspita, H. R. (2015). Adiwiyata Mewujudkan Sekolah yang Berbudaya Lingkungan., (Online), (http://bp2sdm.menlhk.go.id/emagazine/index.php/umum/59-adiwiyata-mewujudkan-sekolahyang-berbudaya-lingkungan.html), diakses 13 Maret 2017.

Sagala, S. (2006). Konsep dan Makna Pembelajaran: Untuk Membantu memecahkan Problematika Belajar Dan Mengajar. Bandung: Alfabeta.

Siagian, S. P. (2003). Filasafat Administrasi. Jakarta: Bumi Aksara.

Sugiyono. (2008). Memahami Penelitian Kualitatif. Bandung: Alfabeta.

Sugiyono. (2011. Metode Penelitian Kuantitatif, Kualitatif, dan R \& D. Bandung: Alfabeta.

Ulfatin, N. (2013). Metodologi Penelitian Kualitatif di Bidang Pendidikan Teori dan Aplikasinya. Malang: Kementerian Pendidikan dan Kebudayaan Universitas Negeri Malang.

Usman, H. (2009). Manajemen: Teori, Praktik, dan Riset Pendidikan. Jakarta: PT Bumi Aksara.

Wiyono, B. B. (2007). Metodologi Penelitian (Pendekatan Kuantitatif, Kualitatif, dan Action Research). Malang: Departemen Pendidikan Nasional Universitas Negeri Malang.

Yasin, S. (2013). Pengertian Lingkungan Sekolah Faktor-faktor yang Mempengaruhi Belajar dalam Lingkungan Sekolah, (Online), (http://www.sarjanaku.com/2013/04/pengertian-lingkungan-sekolahfaktor.html), diakses 3 Februari 2017. 